\title{
Stem Cell Therapy: Pieces of the Puzzle
}

\author{
John A. Schoenhard • Antonis K. Hatzopoulos
}

Received: 21 September 2009 / Accepted: 27 October 2009/Published online: 19 November 2009

(C) The Author(s) 2009. This article is published with open access at Springerlink.com

\begin{abstract}
Acute ischemic injury and chronic cardiomyopathies can cause irreversible loss of cardiac tissue leading to heart failure. Cellular therapy offers a new paradigm for treatment of heart disease. Stem cell therapies in animal models show that transplantation of various cell preparations improves ventricular function after injury. The first clinical trials in patients produced some encouraging results, despite limited evidence for the long-term survival of transplanted cells. Ongoing research at the bench and the bedside aims to compare sources of donor cells, test methods of cell delivery, improve myocardial homing, bolster cell survival, and promote cardiomyocyte differentiation. This article reviews progress toward these goals.
\end{abstract}

Keywords Heart Failure · Myocardial Infarction

Stem Cells · Cell Therapy · Cardiac Regeneration

Cardiovascular disease remains the leading cause of death worldwide. Current therapies seek to prevent atherosclerosis through risk factor modification and to manage the consequences of thrombosis after injury has occurred. Regenerative medicine offers a new paradigm for treatment of heart disease. Stem cell therapies may improve ventricular

J. A. Schoenhard · A. K. Hatzopoulos $(\bowtie)$

Department of Medicine, Division of Cardiovascular Medicine,

Vanderbilt University,

MRB IV P425C, 2213 Garland Avenue,

Nashville, TN 37232, USA

e-mail: antonis.hatzopoulos@vanderbilt.edu

J. A. Schoenhard · A. K. Hatzopoulos

Department of Cell and Developmental Biology,

Vanderbilt University,

MRB IV P425C, 2213 Garland Avenue,

Nashville, TN 37232, USA function after injury through either direct or indirect means, by engraftment and differentiation into cardiac and vascular cells or by secretion of paracrine factors that promote tissue survival and recovery. Thus far, the results of animal studies and clinical trials have been encouraging, despite limited evidence for the long-term survival of transplanted cells.

In contrast to conventional therapies where defined pipelines lead from target identification to drug discovery and development, cardiovascular cell therapies are evolving by a much more diffuse process, more akin to a group of investigators working to solve a puzzle. Pieces of this cell therapy puzzle may now be defined, so that they can be refined and assembled through ongoing study and collaboration. These pieces include (1) the cell types available for transplant, (2) the methods of cell delivery, (3) the means of myocardial homing, (4) the pathways of cell survival, and (5) the goals of cell differentiation.

\section{Stem Cell Populations with Potential for Cardiac Regeneration}

Over the past decade, many cell types have been evaluated in an effort to find the best source for cardiac regeneration. Of these, the most extensively studied have been embryonic stem cells, mesenchymal stem cells, skeletal myoblasts, and bone marrow-derived progenitor cells, while more recent possibilities have included induced pluripotent stem cells and resident cardiac stem cells.

Embryonic stem cells (ESCs) can be obtained from the inner cell mass of a pre-implantation blastocyst and expanded in vitro almost indefinitely without loss of pluripotency [1-3]. When allowed to differentiate as embryoid bodies, ESCs give rise to most somatic lineages, including cardiovascular lineages [4-8]. Culture of em- 
bryoid bodies with specific growth factors or small molecules can drive differentiation toward cardiovascular phenotypes, thereby enriching the pool of ESC-derived cardiac cells available for transplant [8-13]. Both pluripotent ESCs and committed ESC-derived cardiac cells have been tested in rodent models with encouraging results in terms of engraftment, survival, and improvement in ventricular function [14-16]. However, no clinical trials have been attempted, for concerns of teratoma formation [16, 17], graft-versus-host disease [18], and bioethics. While improved in vitro differentiation of ESCs may eliminate the first of these concerns, recent discoveries indicating that adult somatic cells can be reprogrammed to yield ESC-like cells may eliminate the second and third of these issues.

Induced pluripotent stem cells (iPSCs) can be generated from murine and human adult somatic cells by overexpression of transcription factors critical for maintenance of ESC pluripotency. While initial iPSC protocols required retro- or lentiviral transfer of four factors, namely Octamerbinding transcription factor $3 / 4$ (Oct 3/4), Sry-related HMG-box transcription factor (Sox2), Krüppel-like factor 4 , and cellular myelocytomatosis oncogene $[19,20]$ or Oct 3/4, Sox2, Nanog, and Lin28 [21], subsequent reports have reduced the risk of tumorigenesis introduced during the dedifferentiation process by utilizing non-integrating technologies [22-25] or by transferring fewer transcription factors [26-28] while still achieving pluripotency. Once established, iPSCs differentiate much like ESCs, yielding functional cardiovascular lineages from embryoid bodies in vitro [28-32] and contributing to normal cardiovascular development from chimeric blastocysts in vivo [28, 31, 33]. In an initial proof-of-principle study, four-factor iPSCs successfully restored myocardial structure and function after coronary artery ligation in mice [33]. Thus, iPSCs may provide an unlimited supply of autologous donor cells, once technological advancements eliminate the risk of teratoma or other tumor formation.

Mesenchymal stem cells (MSCs) can be separated from bone marrow and adipose tissues based on their adherence to a culture dish [34]. MSCs most readily differentiate into osteoblasts, chondrocytes, and adipocytes $[35,36]$ but can be induced to differentiate into cardiomyocytes under special conditions [37-39]. They can be rapidly expanded in culture, thereby allowing for autologous transplantation, and they may be less immunogenic than other cell populations, thereby allowing for allogenic transplantation $[40,41]$. But, their propensity to differentiate into noncardiac tissues (e.g., heterotopic ossification) currently limits their use $[42,43]$. Nonetheless, at least one clinical trial has shown improved ventricular function at 3 and 6 month follow-up after intracoronary infusion of autologous MSCs postinfarction [44].
Skeletal myoblasts, also known as satellite cells, can be harvested from muscle biopsies, expanded in culture, and autologously reimplanted, albeit on a timescale more appropriate for chronic heart failure therapy than for early postinfarction management. As these cells are further differentiated than ESCs, they are less prone to teratoma formation; they are also more resistant to ongoing ischemia and more apt to function in a contractile capacity postengraftment. However, true cardiomyocyte differentiation has not been observed in vivo. As a result, although skeletal myoblasts may be incorporated into an infarct site, their contractions are dyssynchronous due to failure of electromechanical coupling with the surrounding myocardium $[45,46]$. Thus, no significant benefit has been seen in large-scale clinical trials, while a trend toward more frequent arrhythmias has been observed [47].

Bone marrow-derived mononuclear cells, including hematopoietic and endothelial progenitor cells, can be mobilized with cytokine therapy or harvested by standard collection techniques. In culture, they can differentiate into cardiomyocytes, endothelial cells, and smooth muscle cells [48-51], and after transplant, they can supply a broad range of paracrine factors with proangiogenic, positive remodeling, and antiapoptotic properties [52]. A meta-analysis of 18 randomized and non-randomized trials involving 999 patients with acute myocardial infarction or chronic ischemic cardiomyopathy found that intracoronary infusion of adult bone marrow-derived stem cells improved left ventricular ejection fraction by $3.7 \%$, decreased infarct scar size by $5.5 \%$, and lowered left ventricular end-systolic volume by $4.8 \mathrm{ml}(p<0.01$ for each index) [53]. Among these pooled studies, the largest randomized trial, REPAIR-AMI, was particularly notable for not only demonstrating improvement in ventricular function but also for reducing the combined endpoint of death, myocardial infarction, or revascularization at 12 months when compared with placebo [54]. Nonetheless, controversy remains regarding the fates of bone marrow-derived cells used for cardiac regeneration [55].

\section{Spatiotemporal Aspects of Stem Cell Delivery}

Identification of the most safe and efficacious means of stem cell delivery remains an important challenge, both in terms of route and timing of administration. Current methods of stem cell delivery include non-invasive mobilization from resident niches (especially bone marrow) with cytokine therapy, non-selective intravenous or intracavitary injection, selective intracoronary infusion, and intramyocardial injection from either surgical or percutaneous access. 
Although some intravenously injected bone marrowderived stem cells do home to the infarct border zone, only a small fraction $(<5 \%)$ of intravenously injected cells is retained in this intended destination. Rather, the majority of intravenously injected cells are trapped by the lungs, liver, kidneys, and spleen [56, 57]. More proximal but still nonselective delivery via intracavitary or intra-aortic (with the distal aorta occluded) injection marginally improves cardiac uptake [56, 57], suggesting that closer may be better. Such reasoning underlies the majority of clinical trials which have used intracoronary delivery techniques. Indeed, intracoronary delivery appears superior to intravenous delivery in man $[58,59]$, although overall cell retention remains low as rapid washout follows balloon deflation [60]. Clinical trials assessing the biodistribution of infused cells have recently been reviewed [61].

In animal studies, intramyocardial delivery yields better retention than intracoronary delivery $[57,62,63]$. But so far, no clinical trial has directly compared these two modalities, although such results should be forthcoming [64]. In theory, intramyocardial delivery may provide more precisely targeted therapy without need for patent coronary arteries, while intracoronary delivery may benefit from operator familiarity and lower cost. Since intramyocardial injections carry risk of myocardial perforation and electrical instability shortly after infarction, these two strategies in fact may be complementary, with intracoronary cell delivery provided early and intramyocardial cell delivery provided late.

Despite the potential importance of correctly timing stem cell administration, few studies have directly addressed this issue. On one hand, stem cell survival may be compromised shortly after infarction by transient microvascular obstruction, recurrent ischemia, or reperfusion injury. On the other hand, stem cell homing to the infarct border zone may be enhanced shortly after injury by transient upregulation of cytokines such as stromal cell-derived factor 1 (SDF-1), vascular endothelial growth factor (VEGF), hepatocyte growth factor (HGF), and monocyte chemotactic protein-3 (MCP-3) [65-68]. In rodents, this latter phenomenon appears to have the upper hand, as the benefits of MSC therapy are seen only when administered within 4 days postmyocardial infarction, paralleling myocardial SDF-1 expression [67].

In man, the optimum timing of stem cell therapy may be different. So far, stem cell administration within 1 day of reperfusion therapy has not shown clinical benefit [69] Therefore, the NIH Cardiovascular Cell Therapy Research Network's TIME trial will compare an early time point of 3 days postmyocardial infarction to an intermediate time point of 7 days postmyocardial infarction for intracoronary stem cell infusion [ [70]; http://ccct.sph.uth.tmc.edu/cctrn/ Public/PublicHome.aspx]. This trial will run in parallel with a related study called LATE-TIME, which will focus on a late time point of 2-3 weeks postmyocardial infarction for intracoronary cell infusion. Beyond that time point, a recent substudy of the MYSTAR trial found no significant differences in the long-term improvements in infarct size and ventricular function observed after bone marrow mononuclear cell delivery at 3-6 weeks versus 34 months [71].

\section{Means of Improving Myocardial Homing}

Treatments designed to improve stem cell homing to diseased myocardium have the potential to markedly enhance both the safety and efficacy of cardiovascular cell therapy. By increasing cardiac retention, stem cell capture by non-cardiac tissues may be reduced, thereby limiting potential side effects. This may allow stem cell dosages to be increased, even as outcomes on a per cell basis are improved. Alternatively, decreased stem cell numeric requirements may reduce cell culture and delivery costs.

Many current strategies to improve cardiovascular homing aim to enhance adhesion protein and cytokine interactions between donor cells and host tissues. Ex vivo conditioning of donor cells, for example, by incubation of endothelial progenitor cells with a $\beta 2$-integrin activating antibody, can improve retention and transcapillary migration at sites of injury, where intracellular adhesion molecule-1 (ICAM-1) and fibrinogen are upregulated [72]. Alternatively, in vivo conditioning of the host vasculature, for example, by infusion of adenosine, can promote cardiac retention of endothelial progenitor cells by upregulating coronary artery expression of P-selectin [73]. Increased display of this cell adhesion protein captures endothelial progenitor cells that constitutively express P-selectin glycoprotein ligand-1 [73, 74]. Adenosine can be safely infused into the human coronary circulation [75]; thus, it could be an adjuvant to many existing cell therapy protocols.

Other potential homing agents remain in pre-clinical development. These include master regulators of ischemic responsiveness such as integrin-linked kinase (ILK) and hypoxia inducible factor- $1 \alpha$ (HIF-1 $\alpha)$, as well as secreted homing factors such as SDF-1, MCP-3, and VEGF. In response to hypoxia, ILK is stabilized by heat shock protein 90. Increased ILK activity then leads to increased expression of SDF-1 and ICAM- 1 through HIF- $1 \alpha$ - and nuclear factor $\mathrm{kB}$-mediated signaling [76]. This results in endothelial progenitor cell recruitment to ischemic tissues [76]. While this beneficial property of ILK has been demonstrated only in a hindlimb ischemia model thus far, its cardiac application is likely not far off. Already, it is known that SDF-1 recruits endothelial progenitor cells expressing 
CXCR4 to injured myocardium [65], and ICAM-1 binding to its receptor, $\beta 2$ integrin, on endothelial progenitor cells is required for engraftment after myocardial infarction [77]. Therefore, given the functional improvements seen with ILK gene therapy after coronary artery ligation in rats [78], utilization of ILK in stem cell therapy would seem a logical step.

Indeed, encouraging results have been obtained when local myocardial therapy has been combined with stem cell transplantation. Downstream of ILK, HIF-1 $\alpha$ regulates both SDF-1 and its receptor CXCR4, as well as ICAM-1 [76, 79, 80]. Combining intramyocardial injection of adenovirusencoded HIF-1 $\alpha$ with transplantation of skeletal myoblasts results in improved cell engraftment and cell survival after coronary artery ligation in rats [81]. This results in marked improvement in ejection fraction (by 27\%) at 1 month posttherapy over baseline at 1 week postinfarct. In comparison, monotherapy with HIF-1 $\alpha$ or myoblasts alone serves only to prevent further decline of the ejection fraction over this interval [81].

Further down this ischemic response pathway, both SDF-1 and its receptor CXCR4 have been used successfully as adjuncts to cardiac cell therapy. In mice, endogenous SDF-1 is upregulated for less than 1 week after myocardial infarction [65-67]. Re-establishment of SDF-1 expression at later time points can enhance stem cell recruitment and retention when the ischemic border zone might be less hostile to cell engraftment and survival. Indeed, intramyocardial delivery of scaffold-bound SDF-1 after coronary artery ligation in rats and mice results in enhanced c-Kit + cell homing and improved ventricular function [82, 83].

Cell-based gene therapy can provide a similar biological scaffold. While it may seem counterintuitive for a stem cell to deliver its own homing factor, considerable benefit has been obtained when genetically modified stem cells recruit additional native and transplanted cells to injured myocardium. For example, improved cell engraftment and survival, as well as improved ventricular function, has been observed after transplantation of SDF-1-expressing skeletal myoblasts (as opposed to unmodified skeletal myoblasts) at both early and late time points after myocardial infarction in rats [84, 85]. Similarly, transplantation of SDF-1expressing cardiac fibroblasts promotes homing of endogenous CD117+ stem cells to injured myocardium [65]. This results in improved ventricular function even without cardiomyocyte regeneration [65]. Rather, improved engraftment and differentiation of transplanted SDF-1-expressing MSCs (as opposed to unmodified MSCs) into myofibroblasts, but not true cardiomyocytes, results in improved ventricular function by providing trophic support for cardiomyocyte preservation - but not regeneration-after infarction [86]. Similar results are obtained after transplan- tation of CXCR4-overexpressing MSCs [87], indicating that improved stem cell homing, engraftment, and paracrine activity can be obtained via cell-based gene therapy with both stem cell homing factors and their receptors.

Other growth factor-chemokine-receptor pairs, which may be utilized to improve outcomes of cardiac cell therapy, include VEGF-Flk-1, HGF-c-Met, MCP-3-CCR1/2, and growth-related oncogene-1-CXCR1/2 [66, 68, 88-91]. Of these, the most extensively studied factor is VEGF. VEGF is transiently upregulated after myocardial infarction [66] and serves to mobilize endothelial progenitor cells while promoting neovascularization [92, 93]. VEGF is both induced by SDF-1 and an inducer of SDF-1's receptor CXCR4 [94 96]. Early clinical trials demonstrated that intramyocardial delivery of naked plasmid-encoded VEGF gene therapy is safe but results in only marginal clinical benefit $[97,98]$. Subsequent human and large animal studies of combination intramyocardial VEGF gene delivery plus stem cell therapy have yielded mixed results [99-101]. Meanwhile, VEGFtransfected stem cells have consistently outperformed untransfected control cells after coronary artery ligation in rodents [102-107]. And in those studies that have compared cell-based gene therapy to direct gene delivery, VEGFtransfected skeletal myoblasts and VEGF-transfected MSCs have improved ventricular function to a greater degree than either direct adenoviral injection or liposomal plasmid delivery, respectively [106, 107]. Taken together, these results suggest that cell-based gene therapy may be more effective than either unmodified stem cell therapy or acellular gene therapy alone. The degree to which this principle is generalizable remains to be seen.

\section{Enhancement of Transplanted Cell Survival}

Despite the structural and functional benefits of stem cell therapy in animal and human studies of acute myocardial infarction and chronic heart failure, limited transplanted cell survival has been observed, especially in the long-term. Less than $1 \%$ of transplanted cells survive in patient hearts [108], and even in the idealized scenario of syngeneic neonatal cardiomyocyte intramyocardial injection in healthy rats, only $15 \%$ of transplanted cells survive for 12 weeks [109]. Nonetheless, recent discoveries demonstrative of the heart's capacity for regeneration and repair suggest that these challenges are not insurmountable. Measurement of ${ }^{14} \mathrm{C}$ in the DNA of individuals born prior to Cold War era nuclear testing estimates that nearly half of all cardiomyocytes are exchanged during a normal life span [110]. Since ${ }^{14} \mathrm{C}$ is incorporated equally by the division of resident cardiomyocytes and circulating progenitor cells, carbon dating cannot distinguish the cellular origins of such impressive turnover. Rather, the phenomenon of cardiac 
chimerism seen after sex-mismatched heart or bone marrow transplant confirms that extra-cardiac progenitor cells are capable of long-term engraftment and survival in the healthy human heart [111]. Thus, the challenge for cardiac cell therapy is to strengthen donor cells for the harsh microenvironment of the infarcted heart.

Ischemic preconditioning has long been recognized as a means of improving myocardial ischemic tolerance [112]. In addition to activating survival pathways in cardiomyocytes, ischemic preconditioning recruits endothelial progenitor cells to serve as mobile reservoirs of cardioprotective cytokines [113]. Proponents of cardiac cell therapy now seek to harness this property to enhance donor cell survival. Hypoxic preconditioning of mesenchymal stem cells and cardiac progenitor cells prior to transplant improves not only their recruitment, survival, and differentiation at the infarct border zone but also overall ventricular structure and function [114, 115]. Similar benefits might be obtained by hypoxic preconditioning of endothelial progenitor cells, based on results from an ischemic hindlimb model [116]. This is because, in each of these cell types, hypoxic preconditioning upregulates a diverse array of survival, angiogenic, and migratory proteins, including HIF-1 $\alpha$, Akt-1, Bcl-2, Ang-1, VEGF and its receptor Flk-1, SDF-1's receptor CXCR4, and HGF's receptor c-Met $[114,115,117]$. Together, these factors allow donor cells not only to endure but also to heal the injured myocardium.

Extending this concept, hypoxic preconditioning can be mimicked by genetic modification of donor cells to overexpress hypoxia-responsive survival factors. Akt-1 is activated by hypoxia and other stimuli, including cytokines. As a general mediator of survival signaling, Akt-1 is both necessary and sufficient for cell survival in a variety of settings [118]. Blockade of Akt-1 activation with the phosphoinositol 3-kinase (PI3K) inhibitor wortmannin attenuates the cardioprotective effects of endothelial progenitor cell therapy after ischemic injury in pigs [119]. On the other hand, genetic modification of MSCs to overexpress Akt-1 results in marked improvement in intracardiac MSC retention and survival in rat and pig infarct models $[120,121]$. In both species, transplantation of Akt-1overexpressing MSCs also normalizes ventricular function.

Follow-up studies have demonstrated that Akt-1overexpressing MSCs release paracrine factors that promote myocardial survival and recovery after infarction [122, 123]. By means of functional genomics, secreted frizzled related protein 2 (Sfrp2) was identified as the key Akt-1MSC-expressed paracrine factor mediating myocardial survival and repair after ischemic injury [123]. When Sfrp2 is suppressed in Akt-1-MSCs, the ability of these cells to repair injured myocardium is lost [123]. Alternatively, genetic modification of MSCs to specifically overexpress Sfrp2 promotes their retention and survival within the infarct border zone, as well as facilitates restoration of cardiac structure and function after infarction [124]. These benefits may be attributable to Sfrp2-mediated inhibition of Wnt binding to the frizzled receptor, which results in accumulation of $\beta$-catenin and upregulation of antiapoptotic and proangiogenic signaling.

Other paracrine factors upregulated in Akt-1-MSCs include thymosin $\beta 4$ (T $\beta 4)$ and insulin-like growth factor1 (IGF-1) [122]. T $\beta 4$ is a secreted, G-actin sequestering, 43 amino-acid peptide that stimulates the migration and survival of cardiomyocytes and endothelial cells [125], as well as the migration and differentiation of epicardial coronary vascular progenitors [126]. After coronary artery ligation in mice, intramyocardial injection of $\mathrm{T} \beta 4$ protein activates ILK and Akt-1, limits scar formation, and improves ventricular function [125]. Exemplary of T $\beta 4$ 's importance in cell therapy, shRNA-mediated knockdown of $\mathrm{T} \beta 4$ in endothelial progenitor cells blocks the cardioprotective actions of these cells after ischemia-reperfusion in mice [127].

In addition to stimulating myocardial growth and contractility, IGF-1 activates the PI3K/Akt-1 pathway to promote cardiomyocyte survival and proliferation in response to injury $[128,129]$. IGF-1 protein has been combined with cell therapy to improve donor cell survival and differentiation in host myocardium [130, 131]. Extending these benefits, IGF-1 cell-based gene therapy has improved donor cell engraftment and proliferation and enhanced host cell recruitment to ischemic myocardium $[132,133]$. This has been accompanied by decreased infarct size, increased angiogenesis, and improved ventricular function. Molecular studies have attributed IGF-1's therapeutic benefit, in part, to activation of PI3K/Akt-1 and Bcl-2 and to release of SDF-1 and VEGF [132, 133].

Downstream of IGF-1 and PI3K/Akt-1, but not Sfrp2 [123], Bcl-2 has been identified as a key antiapoptotic protein with potential utility in cardiac cell therapy. Bcl-2 preserves mitochondrial integrity during ischemia and is upregulated by ischemic preconditioning [134]. Cell lines derived from ESCs which overexpress Bcl-2 self-renew continuously, even in the absence of serum and feeder cells [135]. This gives a marked survival advantage to Bcl-2 overexpressing donor cells upon cardiac transplant. Indeed, MSCs, smooth muscle cells, and cardiomyoblasts genetically modified to overexpress Bcl-2 have all demonstrated reduced cell loss and improved ventricular function after transplant into ischemic myocardium [136-138]. But while such results may be encouraging, cell-based gene therapy utilizing cell survival factors is not without its challenges, as these proteins may predispose to tumorigenesis. Much work still lies ahead to regulate the expression of these factors before their clinical application. 


\section{Attaining Cardiomyocyte Regeneration}

Myocardial regeneration after injury has long been the goal of cardiac cell therapy. However, recent experience has shown that cell therapy is capable of providing significant structural and functional benefit with only minimal cardiomyocyte regeneration. As we have discussed, donor cells can recruit host cells to the site of injury, especially if they are modified to overexpress stem and progenitor cell homing factors. Donor cells can secrete paracrine factors to promote host tissue preservation and repair, especially if they are modified to overexpress survival or growth factors [52, 122, 123, 133], and donor muscle cells can provide contractile reserve, especially if they are modified to overexpress connexins essential for electromechanical coupling [139]. Given these capabilities, one might legitimately ask if the last piece of the cardiac cell therapy puzzle - cardiomyocyte regeneration - even needs to be solved.

We would argue that cardiomyocyte regeneration remains a worthy and attainable goal. As we have discussed, recent measurements of ${ }^{14} \mathrm{C}$ incorporation into the heart indicate that nature provides for cardiac regeneration throughout a normal human lifetime [110]. Our challenge is to nurture that process after injury. Genetic fate-mapping studies have shown that nearly $20 \%$ of cardiomyocytes bordering a murine myocardial infarction are derived from endogenous stem or precursor cell differentiation [140]. Cell therapy aims to increase that ratio. This may be accomplished by utilization of more committed cardiac progenitor cells isolated from the adult heart or derived in culture from pluripotent stem cells.

The adult heart is home to a side population (SP) of stem cells identified by exclusion of the vital dyes Hoechst 33342 and rhodamine 123 [141, 142]. Isolated cardiac SP cells that express stem cell antigen-1 (Sca-1+), but are negative for the endothelial marker CD31, are capable of differentiation into functional cardiomyocytes after coculture with adult cardiomyocytes [143] or treatment with a cocktail of bone morphogenetic protein 2, fibroblast growth factors 4 and 8, the Wnt antagonist Dickkoff-1, and 5-azacytidine [144]. Transplantation of both predifferentiated and undifferentiated Sca-1+/CD31- cells after myocardial infarction in mice results in efficient homing, engraftment, and differentiation into cardiomyocytes and endothelial cells, as well as improved ventricular function [144-146].

A second resident progenitor population comprises c-Kit (also known as CD117) positive cells, which are located in small clusters within the adult heart [147]. Isolated c-Kit+ cells do not differentiate into cardiovascular cell types in culture but showed impressive regenerative potential in some studies after transplantation into the injured rat heart, where they gave rise to cardiomyocytes, endothelial cells, and smooth muscle cells, while also improving ventricular function [147-150]. However, these results have not been reproduced in all studies [55]. Nonetheless, a rare Sca- $1+/ \mathrm{c}-$ Kit + cardiac cell type that differentiates into cardiomyocytes upon oxytocin treatment has been identified in mice [151].

From a technical standpoint, cardiac progenitor cells can be isolated from mouse hearts and human endomyocardial biopsies by enzymatic digestion to release round cells that form so-called cardiospheres in suspension [152, 153]. Cardiosphere-derived cells express endothelial and stem cell markers, show contractile activity in culture, and can differentiate into cardiomyocytes, endothelial cells, and smooth muscle cells. Transplantation of these cells improves ventricular function after myocardial infarction in mice and swine, due to both direct cardiomyocyte regeneration and indirect paracrine action [153-155]. To test whether these presumably committed cardiac progenitor cells have benefit in man, enrollment in the first clinical trial of "Cardiosphere-derived autologous stem cells to reverse ventricular dysfunction" (i.e., the CADUCEUS trial) is now underway [156].

An alternative to laborious isolation of committed cardiac progenitor cells from the adult heart is differentiation of committed cardiac progenitor cells from embryonic stem cells, induced pluripotent stem cells, or other multipotent cellular resources such as adipose tissue-derived MSCs. After study of many different growth factor cocktails, a growing consensus now agrees that modulation of bone morphogenetic protein (BMP) signaling may be the key to reliable ex vivo cardiomyocyte differentiation. However, consensus is lacking with regard to identification of the critical BMP agonists and antagonists, as well as their appropriate dosing. Treatment of murine ESCs or MSCs with BMP2 in the presence of a second growth factor such as transforming growth factor- $\beta 1$, fibroblast growth factor 2 or 4 , or leukemia inhibitory factor promotes cardiomyocyte differentiation and improves cardiac structure and function following transplantation into infarcted myocardium $[8,9$, 11, 157]. Similar treatment of human ESCs with BMP4 also promotes cardiomyogenesis [13]. However, it is also known that the endogenous BMP antagonist Noggin and the synthetic BMP inhibitor dorsomorphin also increase cardiomyocyte differentiation [10-12], in apparent contrast to studies that blocked the inductive properties of BMP2 and BMP4 with Noggin $[8,13]$. A unifying hypothesis for these observations suggests that BMP signaling is necessary for at least two steps in cardiomyocyte development: mesodermal induction and cardiomyocyte differentiation [158, 159], between which transient block of BMP signaling is essential [10]. Thus, the optimal timing and dosage of BMP agonist and antagonist treatments may be critical. Finally, recent evidence that adult cardiomyocytes may be induced to 
proliferate could provide a complementary strategy for cardiac regeneration [160].

Ongoing research at the bench and the bedside will surely continue to perfect these pieces of the cardiac cell therapy puzzle: comparing sources of donor cells, testing methods of cell delivery, augmenting myocardial homing, bolstering cell survival, and promoting cardiomyocyte differentiation, and while much more work needs to be done, we have confidence that stem cell therapies in conjunction with current treatment modalities will ultimately reduce the mortality and improve the quality of life of patients with cardiovascular disease.

Acknowledgements This work was supported by NIH grants HL083958 and HL087403.

Open Access This article is distributed under the terms of the Creative Commons Attribution Noncommercial License which permits any noncommercial use, distribution, and reproduction in any medium, provided the original author(s) and source are credited.

\section{References}

1. Evans, M. J., \& Kaufman, M. H. (1981). Establishment in culture of pluripotential cells from mouse embryos. Nature, 292, $154-156$.

2. Martin, G. R. (1981). Isolation of a pluripotent cell line from early mouse embryos cultured in medium conditioned by teratocarcinoma stem cells. Proceedings of the National Academy of Sciences of the United States of America, 78, 7634-7638.

3. Thomson, J. A., Itskovitz-Eldor, J., Shapiro, S. S., Waknitz, M. M., Swiergiel, J. J., Marshall, V. S., et al. (1998). Embryonic stem cell lines derived from human blastocysts. Science, 282, $1145-1147$.

4. Kehat, I., Kenyagin-Karsenti, D., Snir, M., Segev, H., Amit, M., Gepstein, A., et al. (2001). Human embryonic stem cells can differentiate into myocytes with structural and functional properties of cardiomyocytes. Journal of Clinical Investigation, $108,407-414$

5. Xu, C., Police, S., Rao, N., \& Carpenter, M. K. (2002). Characterization and enrichment of cardiomyocytes derived from human embryonic stem cells. Circulation Research, 91, 501508.

6. Kattman, S. J., Huber, T. L., \& Keller, G. M. (2006). Multipotent flk-1+ cardiovascular progenitor cells give rise to the cardiomyocyte, endothelial, and vascular smooth muscle lineages. Developmental Cell, 11, 723-732.

7. Moretti, A., Caron, L., Nakano, A., Lam, J. T., Bernshausen, A., Chen, Y., et al. (2006). Multipotent embryonic isl1+ progenitor cells lead to cardiac, smooth muscle, and endothelial cell diversification. Cell, 127, 1151-1165.

8. Behfar, A., Zingman, L. V., Hodgson, D. M., Rauzier, J.-M., Kane, G. C., Terzic, A., et al. (2002). Stem cell differentiation requires a paracrine pathway in the heart. FASEB Journal, 16, $1558-1566$.

9. Kawai, T., Takahashi, T., Esaki, M., Ushikoshi, H., Nagano, S., Fujiwara, H., et al. (2004). Efficient cardiomyogenic differentiation of embryonic stem cell by fibroblast growth factor 2 and bone morphogenetic protein 2. Circulation Journal, 68, 691702 .
10. Yuasa, S., Itabashi, Y., Koshimizu, U., Tanaka, T., Sugimura, K., Kinoshita, M., et al. (2005). Transient inhibition of BMP signaling by Noggin induces cardiomyocyte differentiation of mouse embryonic stem cells. Nature Biotechnology, 23, 607611.

11. Rajasingh, J., Bord, E., Hamada, H., Lambers, E., Qin, G., Losordo, D. W., et al. (2007). STAT3-dependent mouse embryonic stem cell differentiation into cardiomyocytes: analysis of molecular signaling and therapeutic efficacy of cardiomyocyte precommitted mES transplantation in a mouse model of myocardial infarction. Circulation Research, 101, 910-918.

12. Hao, J., Daleo, M. A., Murphy, C. K., Yu, P. B., Ho, J. N., Hu, J., et al. (2008). Dorsomorphin, a selective small molecule inhibitor of BMP signaling, promotes cardiomyogenesis in embryonic stem cells. PLoS ONE, 3, e2904.

13. Takei, S., Ichikawa, H., Johkura, K., Mogi, A., No, H., Yoshie, S., et al. (2009). Bone morphogenetic protein-4 promotes induction of cardiomyocytes from human embryonic stem cells in serum-based embryoid body development. American Journal of Physiology Heart and Circulation Physiology, 296, 17931803.

14. Min, J. Y., Yang, Y., Converso, K. L., Liu, L., Huang, Q., Morgan, J. P., et al. (2002). Transplantation of embryonic stem cells improves cardiac function in post-infarcted rats. Journal of Applied Physiology, 92, 288-296.

15. Laflamme, M. A., Chen, K. Y., Naumova, A. V., Muskheli, V., Fugate, J. A., Dupras, S. K., et al. (2007). Cardiomyocytes derived from human embryonic stem cells in pro-survival factors enhance function of infarcted rat hearts. Nature Biotechnology, $25,1015-1024$.

16. Behfar, A., Perez-Terzic, C., Faustino, R. S., Arrell, D. K., Hodgson, D. M., Yamada, S., et al. (2007). Cardiopoietic programming of embryonic stem cells for tumor-free heart repair. Journal of Experimental Medicine, 204, 405-420.

17. Nussbaum, J., Minami, E., Laflamme, M. A., Virag, J. A., Ware, C. B., Masino, A., et al. (2007). Transplantation of undifferentiated murine embryonic stem cells in the heart: teratoma formation and immune response. FASEB Journal, 21, 13451357.

18. Swijnenburg, R. J., Tanaka, M., Vogel, H., Baker, J., Kofidis, T., Gunawan, F., et al. (2005). Embryonic stem cell immunogenicity increases upon differentiation after transplantation into ischemic myocardium. Circulation, 112(Suppl. 9), I166-I172.

19. Takahashi, K., \& Yamanaka, S. (2006). Induction of pluripotent stem cells from mouse embryonic and adult fibroblast cultures by defined factors. Cell, 126, 663-676.

20. Takahashi, K., Tanabe, K., Ohnuki, M., Narita, M., Ichisaka, T., Tomoda, K., et al. (2007). Induction of pluripotent stem cells from adult human fibroblasts by defined factors. Cell, 131, 861872.

21. Yu, J., Vodyanik, M. A., Smuga-Otto, K., Antosiewicz-Bourget, J., Frane, J. L., Tian, S., et al. (2007). Induced pluripotent stem cell lines derived from human somatic cells. Science, 318, 19171920.

22. Stadtfeld, M., Nagaya, M., Utikal, J., Weir, G., \& Hochedlinger, K. (2008). Induced pluripotent stem cells generated without viral integration. Science, 322, 945-949.

23. Okita, K., Nakagawa, M., Hyenjong, H., Ichisaka, T., \& Yamanaka, S. (2008). Generation of mouse induced pluripotent stem cells without viral vectors. Science, 322, 949-953.

24. Yu, J., Hu, K., Smuga-Otto, K., Tian, S., Stewart, R., Slukvin, I. I., et al. (2009). Human induced pluripotent stem cells free of vector and transgene sequences. Science, 324, 797-801.

25. Zhou, H., Wu, S., Joo, J. Y., Zhu, S., Han, D. W., Lin, T., et al. (2009). Generation of induced pluripotent stem cells using recombinant proteins. Cell Stem Cell, 4, 381-384. 
26. Huangfu, D., Osafune, K., Maehr, R., Guo, W., Eijkelenboom, A., Chen, S., et al. (2008). Induction of pluripotent stem cells from primary human fibroblasts with only Oct4 and Sox2. Nature Biotechnology, 26, 1269-1275.

27. Shi, Y., Desponts, C., Do, J. T., Hahm, H. S., Scholer, H. R., \& Ding, S. (2008). Induction of pluripotent stem cells from mouse embryonic fibroblasts by Oct4 and Klf4 with small-molecule compounds. Cell Stem Cell, 3, 568-574.

28. Martinez-Fernandez, A., Nelson, T. J., Yamada, S., Reyes, S., Alekseev, A. E., Perez-Terzic, C., et al. (2009). iPS programmed without c-Myc yield proficient cardiogenesis for functional heart chimerism. Circulation Research, 105, 648-656.

29. Narazaki, G., Uosaki, H., Teranishi, M., Okita, K., Kim, B., Matsuoka, S., et al. (2008). Directed and systematic differentiation of cardiovascular cells from mouse induced pluripotent stem cells. Circulation, 118, 498-506.

30. Mauritz, C., Schwanke, K., Reppel, M., Neef, S., Katsirntaki, K., Maier, L. S., et al. (2008). Generation of functional murine cardiac myocyctes from induced pluripotent stem cells. Circulation, 118, 507-517.

31. Schenke-Layland, K., Rhodes, K. E., Angelis, E., Butylkova, Y., Heydarkhan-Hagvall, S., Gekas, C., et al. (2008). Reprogrammed mouse fibroblasts differentiate into cells of the cardiovascular and hematopoietic lineages. Stem Cells, 26, 1537-1546.

32. Zhang, J., Wilson, G. F., Soerens, A. G., Koonce, C. H., Yu, J., Palecek, S. P., et al. (2009). Functional cardiomyocytes derived from human induced pluripotent stem cells. Circulation, 104, e30-e41.

33. Nelson, T. J., Martinez-Fernandez, A., Yamada, S., Perez-Terzic, C., Ikeda, Y., \& Terzic, A. (2009). Repair of acute myocardial infarction by human stemness factors induced pluripotent stem cells. Circulation, 120, 408-416.

34. Alhadlaq, A., \& Mao, J. J. (2004). Mesenchymal stem cells: isolation and therapeutics. Stem Cells and Development, 13, 436-448.

35. Pittenger, M. F., Mackay, A. M., Beck, S. C., Jaiswal, R. K., Douglas, R., Mosca, J. D., et al. (1999). Multilineage potential of adult human mesenchymal stem cells. Science, 284, 143-147.

36. Jiang, Y., Jahagirdar, B. N., Reinhardt, R. L., Schwartz, R. E., Keene, C. D., Ortiz-Gonzalez, X. R., et al. (2002). Pluripotency of mesenchymal stem cells derived from adult marrow. Nature, $418,41-49$.

37. Makino, S., Fukuda, K., Miyoshi, S., Konishi, F., Kodama, H., Pan, J., et al. (1999). Cardiomyocytes can be generated from marrow stromal cells in vitro. Journal of Clinical Investigation, 103, 697-705

38. Tomita, S., Li, R. K., Weisel, R. D., Mickle, D. A., Kim, E. J., Sakai, T., et al. (1999). Autologous transplantation of bone marrow cells improves damaged heart function. Circulation, 100 (Suppl. 19), II247-II256.

39. Shiota, M., Heike, T., Haruyama, M., Baba, S., Tsuchiya, A., Fujino, H., et al. (2007). Isolation and characterization of bone marrow-derived mesenchymal progenitor cells with myogenic and neuronal properties. Experimental Cell Research, 313, 10081023

40. Amado, L. C., Saliaris, A. P., Schuleri, K. H., St. John, M., Xie, J. S., Catteneo, S., et al. (2005). Cardiac repair with intramyocardial injection of allogeneic mesenchymal stem cells after myocardial infarction. Proceedings of the National Academy of Sciences of the United States of America, 102, 11474-11479.

41. Dai, W., Hale, S. L., Martin, B. J., Kuang, J. Q., Dow, J. S., Wold, L. E., et al. (2005). Allogeneic mesenchymal stem cell transplantation in postinfarcted rat myocardium: short- and longterm effects. Circulation, 112, 214-223.

42. Yoon, Y. S., Park, J. S., Tkebuchava, T., Luedeman, C., \& Losordo, D. W. (2004). Unexpected severe calcification after transplantation of bone marrow cells in acute myocardial infarction. Circulation, 109, 3154-3157.

43. Breitbach, M., Bostani, T., Roell, W., Xia, Y., Dewald, O., Nygren, J. M., et al. (2007). Potential risks of bone marrow cell transplantation into infarcted hearts. Blood, 110, 1362-1369.

44. Chen, S. L., Fang, W. W., Ye, F., Liu, Y. H., Qian, J., Shan, S. J., et al. (2004). Effect on left ventricular function of intracoronary transplantation of autologous bone marrow mesenchymal stem cells in patients with acute myocardial infarction. American Journal of Cardiology, 94, 92-95.

45. Reinecke, H., Poppa, V., \& Murry, C. E. (2002). Skeletal muscle stem cells do not transdifferentiate into cardiomyocytes after cardiac grafting. Journal of Molecular and Cellular Cardiology, 34, 241-249.

46. Leobon, B., Garcin, I., Menasche, P., Vilquin, J. T., Audinat, E. \& Charpak, S. (2003). Myoblasts transplanted into rat infracted myocardium are functionally isolated from their host. Proceedings of the National Academy of Sciences of the United States of America, 100, 7808-7811.

47. Menasche, P., Alfieri, O., Janssens, S., McKenna, W., Reichenspurner, H., Trinquart, L., et al. (2008). The Myoblast Autologous Grafting in Ischemic Cardiomyopathy (MAGIC) trial: first randomized placebo-controlled study of myoblast transplantation. Circulation, 117, 1189-2000.

48. Yeh, E. T., Zhang, S., Wu, H. D., Koerbling, M., Willerson, J. T., \& Estrov, Z. (2003). Transdifferentiation of human peripheral blood CD34-enriched cell population into cardiomyocytes, endothelial cells, and smooth muscle cells in vivo. Circulation, 108, 2070-2073.

49. Belema Bedada, F., Technau, A., Ebelt, H., Schulze, M., \& Braun, T. (2005). Activation of myogenic differentiation pathways in adult bone marrow-derived stem cells. Molecular and Cellular Biology, 25, 9509-9519.

50. Badorff, C., Brandes, R. P., Popp, R., Rupp, S., Urbich, C., Aicher, A., et al. (2003). Transdifferentiation of blood-derived human adult endothelial progenitor cells into functionally active cardiomyocytes. Circulation, 107, 1024-1043.

51. Iwasaki, H., Kawamoto, A., Ishikawa, M., Oyamada, A. Nakamori, S., Nichimura, H., et al. (2006). Dose-dependent contribution of CD34-positive cell transplantation to concurrent vasculogenesis and cardiomyogenesis for functional regenerative recovery after myocardial infarction. Circulation, 113, 13111325.

52. Kupatt, C., Horstkotte, G. A., Vlastos, A., Pfosser, C., Lebherz, M., Semisch, M., et al. (2005). Embryonic endothelial progenitor cells expressing a broad range of pro-angiogenic and remodeling factors enhance vascularization and tissue recovery in acute and chronic ischemia. FASEB Journal, 19, 1576-1578.

53. Abdel-Latif, A., Bolli, R., Tleyjeh, I. M., Montori, V. M., Perin, E. C., Hornung, C. A., et al. (2007). Adult bone marrow-derived cells for cardiac repair: a systematic review and meta-analysis. Archives of Internal Medicine, 167, 989-997.

54. Schaechinger, V., Erbs, S., Elsaesser, A., Haberbosch, W., Hambrecht, R., Hoelschermann, H., et al. (2006). Improved clinical outcome after intracoronary administration of bonemarrow-derived progenitor cells I acute myocardial infarction: final 1-year results of the REPAIR-AMI trial. European Heart Journal, 23, 2775-2783.

55. Murry, C. E., Soonpaa, M. H., Reinecke, H., Nakajima, H., Nakajima, H. O., Rubart, M., et al. (2004). Haematopoietic stem cells do not transdifferentiate into cardiac myocytes in myocardial infarcts. Nature, 428, 654-668.

56. Aicher, A., Brenner, W., Zuhayra, M., Badorff, C., Massoudi, S., Assmus, B., et al. (2003). Assessment of the tissue distribution of transplanted human endothelial progenitor cells by radioactive labeling. Circulation, 107, 2134-2139. 
57. Li, S. H., Lai, T. Y., Sun, Z., Han, M., Moriyama, E., Wilson, B., et al. (2009). Tracking cardiac engraftment and distribution of implanted bone marrow cells: comparing intra-aortic, intravenous, and intramyocardial delivery. Journal of Thoracic and Cardiovascular Surgery, 137, 1225-1233.

58. Hofmann, M., Wollert, K. C., Meyer, G. P., Menke, A., Arseniev, L., Hertenstein, B., et al. (2005). Monitoring of bone marrow cell homing into the infracted human myocardium. Circulation, 111, 2198-2202.

59. Kang, W. J., Kang, H. J., Kim, H. S., Chung, J. K., Lee, M. C., \& Lee, D. S. (2006). Tissue distribution of 18F-FDG-labeled peripheral hematopoietic stem cells after intracoronary administration in patients with myocardial infarction. Journal of Nuclear Medicine, 47, 1295-1301.

60. Doyle, B., Kemp, B. J., Chareonthaitawee, P., Reed, C., Schmeckpeper, J., Sorajja, P., et al. (2007). Dynamic tracking during intracoronary injection of $18 \mathrm{~F}-\mathrm{FDG}$-labeled progenitor cell therapy for acute myocardial infarction. Journal of Nuclear Medicine, 48, 1708-1714.

61. Bartunek, J., Sherman, W., Vanderheyden, M., Fernandez-Aviles, F., Wijns, W., \& Terzic, A. (2009). Delivery of biologics in cardiovascular regenerative medicine. Clinical Pharmacology \& Therapeutics, 85, 548-552.

62. Hou, D., Youssef, E. A.-S., Brinton, T. J., Zhang, P., Rogers, P., Price, E. T., et al. (2005). Radiolabeled cell distribution after intramyocardial, intracoronary, and interstitial retrograde coronary venous delivery: implications for current clinical trials. Circulation, 112(Suppl. I), I150-I156.

63. Perin, E. C., Silva, G. V., Assad, J. A. R., Vela, D., Buja, L. M., Sousa, A. L. S., et al. (2008). Comparison of intracoronary and transendocardial delivery of allogeneic mesenchymal cells in a canine model of acute myocardial infarction. Journal of Molecular and Cellular Cardiology, 44, 486-495.

64. Nyolczas, N., Gyongyosi, M., Beran, G., Dettke, M., Graf, S., Sochor, H., et al. (2007). Design and rationale for the Myocardial Stem Cell Administration After Acute Myocardial Infarction (MYSTAR) Study: a multicenter, prospective, randomized, single-blind trial comparing early and later intracoronary or combined (percutaneous intramyocardial and intracoronary) administration of nonselected autologous bone marrow cells to patients after acute myocardial infarction. American Heart Journal, 153, 212.e1-2212.e7.

65. Askari, A. T., Unzek, S., Popovic, Z. B., Goldman, C. K., Forudi, F., Kiedrowski, M., et al. (2003). Effect of stromal-cellderived factor 1 on stem cell homing and tissue regeneration in ischaemic cardiomyopathy. Lancet, 362, 697-703.

66. Kucia, M., Dawn, B., Hunt, G., Guo, Y., Wysoczynski, M., Majka, M., et al. (2004). Cells expressing early cardiac markers reside in the bone marrow and are mobilized into the peripheral blood after myocardial infarction. Circulation Research, 95, 1191-1199.

67. Ma, J., Ge, J., Zhang, S., Sun, A., Shen, J., Chen, L., et al. (2005). Time course of myocardial stromal cell-derived factor 1 expression and beneficial effects of intravenously administered bone marrow stem cells in rats with experimental myocardial infarction. Basic Research in Cardiology, 100, 217-223.

68. Schenk, S., Mal, N., Finan, A., Zhang, M., Kiedrowski, M., Popovic, Z., et al. (2007). Monocyte chemotactic protein-3 is a myocardial mesenchymal stem cell homing factor. Stem Cells, $25,245-251$.

69. Janssens, S., Dubois, C., Bogaert, J., Theunissen, K., Deroose, C., Desmet, W., et al. (2006). Autologous bone marrow-derived stem-cell transfer in patients with ST-elevation myocardial infarction: double-blind, randomized controlled trial. Lancet, $367,113-121$.
70. Traverse, J. H., Henry, T. D., Vaughan, D. E., Ellis, S. G., Pepine, C. J., Willerson, J. T., et al. (2009). Rationale and design for TIME: a phase II, randomized, double-blind, placebocontrolled pilot trial evaluating the safety and effect of timing of administration of bone marrow mononuclear cells after acute myocardial infarction. American Heart Journal, 158, 356-363.

71. Gyongyosi, M., Lang, I., Dettke, M., Beran, G., Graf, S., Sochor, H., et al. (2009). Combined delivery approach of bone marrow mononuclear stem cells early and late after myocardial infarction: the MYSTAR prospective, randomized study. Nature Clinical Practice Cardiovascular Medicine, 6, 70-81.

72. Chavakis, E., Aicher, A., Heeschen, C., Sasaki, K., Kaiser, R., El Makhfi, N., et al. (2005). Role of $\beta 2$-integrins for homing and neovascularization capacity of endothelial progenitor cells. Journal of Experimental Medicine, 201, 63-72.

73. Ryzhov, S., Solenkova, N. V., Goldstein, A. E., Lamparter, M., Fleenor, Y., Young, P. P., et al. (2008). Adenosine receptormediated adhesion of endothelial progenitors to cardiac microvascular endothelial cells. Circulation Research, 102, 356-363.

74. Vajkoczy, P., Blum, S., Lamparter, M., Mailhammer, R., Erber, R., Engelhardt, B., et al. (2003). Multistep nature of microvascular recruitment of ex vivo expanded embryonic endothelial progenitor cells during tumor angiogenesis. Journal of Experimental Medicine, 197, 1755-1765.

75. Lessar, M. A., Stoddard, M., Ahmed, M., Broadbent, J., \& Bolli, R. (1997). Preconditioning of human myocardium with adenosine during coronary angioplasty. Circulation, 95, 25002507.

76. Lee, S. P., Youn, S. W., Cho, H. J., Li, L., Kim, T. Y., Yook, H. S., et al. (2006). Integrin-linked kinase, a hypoxia-responsive molecule, controls postnatal vasculogenesis by recruitment of endothelial progenitor cells to ischemia tissue. Circulation, 114, $150-159$.

77. Wu, Y., Ip, J. E., Huang, J., Zhang, L., Matsushita, K., Liew, C. C., et al. (2006). Essential role of ICAM-1/CD18 in mediating EPC recruitment, angiogenesis, and repair to the infarcted myocardium. Circulation Research, 99, 315-322.

78. Ding, L., Dong, L., Chen, X., Zhang, L., Xu, X., Ferro, A., et al. (2009). Increased expression of integrin-linked kinase attenuates left ventricular remodeling and improves cardiac function after myocardial infarction. Circulation, 120, 764-773.

79. Ceradini, D. J., Kulkarni, A. R., Callaghan, M. J., Tepper, O. M., Bastidas, N., Kleinman, M. E., et al. (2004). Progenitor cell trafficking is regulated by hypoxic gradients through HIF-1 induction of SDF-1. Nature Medicine, 10, 858-864.

80. Staller, P., Sulitkova, J., Lisztwan, J., Moch, H., Oakeley, E. J., \& Krek, W. (2003). Chemokine receptor CXCR4 downregulated by von Hippel-Lindau tumour suppressor pVHL. Nature, 425, 307-311.

81. Azarnoush, K., Maurel, A., Sebbah, L., Carrion, C., Bissery, A., Mandet, C., et al. (2005). Enhancement of the functional benefits of skeletal myoblast transplantation by means of coadministration of hypoxia-inducible factor $1 \alpha$. Journal of Thoracic and Cardiovascular Surgery, 130, 173-179.

82. Zhang, G., Nakamura, Y., Wang, X., Hu, Q., Suggs, L. J., \& Zhang, J. (2007). Controlled release of stromal cell-derived factor-1 alpha in situ increases c-kit+cell homing to the infarcted heart. Tissue Engineering, 13, 2063-2071.

83. Segers, V. F., Tokunou, T., Higgins, L. J., MacGillivray, C., Gannon, J., \& Lee, R. T. (2007). Local delivery of proteaseresistant stromal cell derived factor- 1 for stem cell recruitment after myocardial infarction. Circulation, 116, 1683-1692.

84. Deglurkar, I., Mal, N., Mills, W. R., Popovic, Z. B., McCarthy, P., Blackstone, E. H., et al. (2006). Mechanical and electrical effects of cell-based gene therapy for ischemic cardiomyopathy are independent. Human Gene Therapy, 17, 1144-1151. 
85. Elmadbough, I., Haider, H. K., Jiang, S., Idris, N. M., Lu, G., \& Ashraf, M. (2007). Ex vivo delivered stromal cell-derived factor1alpha promotes stem cell homing and induces angiogenesis in the infarcted myocardium. Journal of Molecular and Cellular Cardiology, 42, 792-803.

86. Zhang, M., Mal, N., Kiedrowski, M., Chacko, M., Askari, A. T., Popovic, Z. B., et al. (2007). SDF-1 expression by mesenchymal stem cells results in trophic support of cardiac myocytes following myocardial infarction. FASEB Journal, 21, 3197-3207.

87. Chen, Z., Ou, L., Zhou, X., Li, F., Jia, X., Zhang, Y., et al. (2008). Targeted migration of mesenchymal stem cells modified with CXCR4 gene to infarcted myocardium improves cardiac performance. Molecular Therapy, 16, 571-579.

88. Urbanek, K., Rota, M., Cascapera, S., Bearzi, C., Nascimbene, A., De Angelis, A., et al. (2005). Cardiac stem cells possess growth factor-receptor systems that after activation regenerate the infarcted myocardium, improving ventricular function and long-term survival. Circulation Research, 97, 663-673.

89. Duan, H. F., Wu, C. T., Wu, D. L., Lu, Y., Liu, H. J., Ha, X. Q., et al. (2003). Treatment of myocardial ischemia with bone marrow-derived mesenchymal stem cells overexpressing hepatocyte growth factor. Molecular Therapy, 8, 467-474.

90. Zhu, X. Y., Zhang, X. Z., Xu, L., Zhong, X. Y., Ding, Q., \& Chen, Y. X. (2009). Transplantation of adipose-derived stem cells overexpressing hHGF into cardiac tissue. Biochemical and Biophysical Research Communications, 379, 1084-1090.

91. Kocher, A. A., Schuster, M. D., Bonaros, N., Lietz, K., Xiang, G., Martens, T. P., et al. (2006). Myocardial homing and neovascularization by human bone marrow angioblasts is regulated by IL-8/Gro CXC chemokines. Journal of Molecular and Cellular Cardiology, 40, 455-464.

92. Asahara, T., Takahashi, T., Masuda, H., Kalka, C., Chen, D., Iwaguro, H., et al. (1999). VEGF contributes to postnatal revascularization by mobilizing bone marrow-derived endothelial progenitor cells. EMBO Journal, 18, 3964-3972.

93. Kalka, C., Masuda, H., Takahashi, T., Gordon, R., Tepper, O., Gravereauz, E., et al. (2000). Vascular endothelial growth factor 165 gene transfer augments circulating endothelial progenitor cells in human subjects. Circulation Research, 86, 1198-1202.

94. Marsha, F., Portal, J., Li, H., Moraine, M., Troche, V., Lybrand, E., et al. (2000). SDF-1 activity on microvascular endothelial cells: consequences on angiogenesis in in vitro and in vivo models. Thrombosis Research, 99, 587-594.

95. Salcedo, R., Wasserman, K., Young, H. A., Grimm, M. C., Howard, O. M., Anver, M. R., et al. (1999). Vascular endothelial growth factor and basic fibroblast growth factor induce expression of CXCR-2 on human endothelial cells. In vivo revascularization induced by stoma-derived factor-1. American Journal of Pathology, 154, 1125-1135.

96. Tang, J., Wang, J., Song, H., Huang, Y., Yang, J., Kong, X., et al. (2009). Adenovirus-mediated stromal cell-derived factor alpha gene transfer improves cardiac structure and function after experimental myocardial infarction through angiogenic and antifibrotic actions. Molecular Biology Reports, [Epub ahead of print].

97. Lorsordo, D. W., Vale, P. R., Hendel, R. C., Milliken, C. E., Fortuin, F. D., Cummings, N., et al. (2002). Phase 1/2 placebocontrolled, double-blind, dose-escalating trial of myocardial vascular endothelial growth factor 2 gene transfer by catheter delivery in patients with chronic myocardial ischemia. Circulation, 105, 2012-2018.

98. Kastrup, J., Jorgensen, E., Rueck, A., Taegil, K., Glogar, D., Ruzyllo, W., et al. (2005). Direct intramyocardial plasmid vascular endothelial growth factor-A165 gene therapy in patients with stable severe angina pectoris: A randomized double-blind placebo-controlled study: The Euroinject One trial. Journal of the American College of Cardiology, 45, 982-988.
99. Chachques, J. C., Duarte, F., Cattadori, B., Shafy, A., Lila, N., Chatellier, G., et al. (2004). Angiogenic growth factors and/or cellular therapy for myocardial regeneration: a comparative study. Journal of Thoracic and Cardiovascular Surgery, 128, 245-253.

100. Kawamoto, A., Murayama, T., Kusano, K., Ii, M., Tkebuchava, T., Shintani, S., et al. (2004). Synergistic effect of bone marrow mobilization and vascular endothelial growth factor-2 gene therapy in myocardial infarction. Circulation, 110, 1398-1405.

101. Ripa, R. S., Wang, Y., Jorgensen, E., Johnsen, H. E., Hese, B., \& Kastrup, J. (2006). Intramyocardial injection of vascular endothelial growth factor-A165 plasmid followed by granulocytecolony stimulating factor to induce angiogenesis in patients with severe chronic ischaemic heart disease. European Heart Journal, 27, 1785-1792.

102. Suzuki, K., Murtuza, B., Smolenski, R. T., Sammut, I. A., Suzuki, N., Kaneda, Y., et al. (2001). Cell transplantation for the treatment of acute myocardial infarction using vascular endothelial growth factor-expressing skeletal myoblasts. Circulation, 104(Suppl. I), I207-I212.

103. Yau, T. M., Fung, K., Weisel, R. D., Fujii, T., Mickle, D. A., \& Li, R. K. (2001). Enhanced myocardial angiogenesis by gene transfer with transplanted cells. Circulation, 104(Suppl. I), I218I222.

104. Yang, Y., Min, J. Y., Rana, J. S., Ke, Q., Cai, J., Chen, Y., et al. (2002). VEGF enhances functional improvement of postinfarcted hearts by transplantation of ESC-differentiated cells. Journal of Applied Physiology, 93, 1140-1151.

105. Matsumoto, R., Omura, T., Yoshiyama, M., Hayashi, T., Inamoto, S., Koh, K. R., et al. (2005). Vascular endothelial growth factor-expressing mesenchymal stem cell transplantation for the treatment of acute myocardial infarction. Arteriosclerosis Thrombosis and Vascular Biology, 25, 1168-1173.

106. Askari, A., Unzek, S., Goldman, C. K., Ellis, S. G., Thomas, J. D., DiCorleto, P. E., et al. (2004). Cellular, but not direct, adenoviral delivery of vascular endothelial growth factor results in improved left ventricular function and neovascularization in dilated ischemic cardiomyopathy. Journal of the American College of Cardiology, 43, 1908-1914.

107. Yang, J., Zhou, W., Ma, Y., Lin, L., Tang, T., Liu, J., et al. (2007). Effects of myocardial transplantation of marrow mesenchymal stem cells transfected with vascular endothelial growth factor for the improvement of heart function and angiogenesis after myocardial infarction. Cardiology, 107, 17-29.

108. Pagani, F. D., DerSimonian, H., Zawadzka, A., Wetzel, K., Edge, A. S. B., Jacoby, D. B., et al. (2003). Autologous skeletal myoblasts transplanted into ischemia-damaged myocardium in humans: histological analysis of cell survival and differentiation. Journal of the American College of Cardiology, 41, 879-888.

109. Mueller-Ehmsen, J., Whittaker, P., Kloner, R. A., Dow, J. S., Sakoda, T., Long, T. I., et al. (2002). Survival and development of neonatal rat cardiomyocytes transplanted into adult myocardium. Journal of Molecular and Cellular Cardiology, 34, 107-116.

110. Bergmann, O., Bhardwaj, R. D., Bernard, S., Zdunek, S., Barnabe-Heider, F., Walsh, S., et al. (2009). Evidence for cardiomyocyte renewal in humans. Science, 324, 98-102.

111. Bayes-Genis, A., Roura, S., Prat-Vidal, C., Farre, J., Soler-Botija, C., Bayes de Luna, A., et al. (2007). Chimerism and microchimerism of the human heart: evidence for cardiac regeneration. Nature Clinical Practice Cardiovascular Medicine, 4(Suppl. 1), S40-S45.

112. Murry, C. E., Jennings, R. B., \& Reimer, K. A. (1986). Preconditioning with ischemia: a delay of lethal cell injury in ischemic myocardium. Circulation, 74, 1124-1136.

113. Ii, M., Nishimura, H., Iwakura, A., Wecker, A., Eaton, E., Asahara, T., et al. (2005). Endothelial progenitor cells are rapidly 
recruited to myocardium and mediate protective effect of ischemic preconditioning via "imported" nitric oxide synthase activity. Circulation, 111, 1114-11120.

114. Hu, X., Yu, S. P., Fraser, J. L., Lu, Z., Ogle, M. E., Wang, J. A., et al. (2008). Transplantation of hypoxia-preconditioned mesenchymal stem cells improves infarcted heart function via enhanced survival of implanted cells and angiogenesis. Journal of Thoracic and Cardiovascular Surgery, 135, 799-808.

115. Tang, Y. L., Zhu, W., Cheng, M., Chen, L., Zhang, J., Sun, T., et al. (2009). Hypoxic preconditioning enhances the benefit of cardiac progenitor cell therapy for treatment of myocardial infarction by inducing CXCR4 expression. Circulation Research, 104, 1209-1216.

116. Akita, T., Murohara, T., Ikeda, H., Sasaki, K., Shimada, T., Egami, K., et al. (2003). Hypoxic preconditioning augments efficacy of human endothelial progenitor cells for therapeutic neovascularization. Laboratory Investigation, 83, 65-73.

117. Rosova, I., Dao, M., Capoccia, B., Link, D., \& Nolta, J. A. (2008). Hypoxic preconditioning results in increased mobility and improved therapeutic potential of human mesenchymal stem cells. Stem Cells, 26, 2173-2182.

118. Datta, S. R., Brunet, A., \& Greenberg, M. E. (1999). Cellular survival: a play in three Akts. Genes \& Development, 13, 29052927.

119. Kupatt, C., Hinkel, R., Lamparter, M., von Bruehl, M.-L., Pohl, T., Horstkotte, J., et al. (2005). Retroinfusion of embryonic endothelial progenitor cells attenuates ischemia-reperfusion injury in pigs: role of PI3-kinase/AKT. Circulation, 112(Suppl. I), I117-I122.

120. Mangi, A. A., Noiseux, N., Kong, D., He, H., Rezvani, M., Ingwall, J. S., et al. (2003). Mesenchymal stem cells modified with Akt prevent remodeling and restore performance of infarcted hearts. Nature Medicine, 9, 1195-1201.

121. Lim, S. Y., Kin, Y. S., Ahn, Y., Jeong, M. H., Hong, M. H., Joo, S. Y., et al. (2006). The effects of mesenchymal stem cells transduced with Akt in a porcine myocardial infarction model. Cardiovascular Research, 70, 530-542.

122. Gnecchi, M., He, H., Noiseux, N., Liang, O. D., Zhang, L., Morello, F., et al. (2006). Evidence supporting paracrine hypothesis for Akt-modified mesenchymal stem cell-mediated cardiac protection and functional improvement. FASEB Journal, 20, 661-669.

123. Mirotsou, M., Zhang, Z., Deb, A., Zhang, L., Gnecchi, M., Noiseux, N., et al. (2007). Secreted frizzled related protein 2 (Sfrp2) is the key Akt-mesenchymal stem cell-released paracrine factor mediating myocardial survival and repair. Proceedings of the National Academy of Sciences of the United States of America, 104, 1643-1648.

124. Alfaro, M. P., Pagni, M., Vincent, A., Atkinson, J., Hill, M. F., Cates, J., et al. (2008). The Wnt modulator sFRP2 enhances mesenchymal stem cell engraftment, granulation tissue formation and myocardial repair. Proceedings of the National Academy of Sciences of the United States of America, 105, 18366-18371.

125. Bock-Marquette, I., Saxena, A., White, M. D., DiMaio, J. M., \& Srivastava, D. (2004). Thymosin $\beta 4$ activates integrin-linked kinase and promotes cardiac cell migration, survival, and cardiac repair. Nature, 432, 466-472.

126. Smart, N., Risebro, C. A., Melville, A. A. D., Moses, K., Schwartz, R. J., Chien, K. R., et al. (2007). Thymosin $\beta 4$ induces adult epicardial progenitor mobilization and neovascularization. Nature, 445, 177-182.

127. Hinkel, R., El-Aouni, C., Olson, T., Horstkotte, J., Mayer, S., Mueller, S., et al. (2008). Thymosin $\beta 4$ is an essential paracrine factor for embryonic endothelial progenitor cell-mediated cardioprotection. Circulation, 117, 2232-2240.

128. Ren, J., Samson, W. K., \& Sowers, J. R. (1999). Insulin-like growth factor I as a cardiac hormone: physiological and pathophysiological implications in heart disease. Journal of Molecular and Cellular Cardiology, 31, 2049-2061.

129. Fujio, Y., Nguyen, T., Wencker, D., Kitsis, R. N., \& Walsh, K. (2000). Akt promotes survival of cardiomyocytes in vitro and protects against ischemia-reperfusion injury in mouse heart. Circulation, 101, 660-667.

130. Kofidis, T., de Bruin, J. L., Yamane, T., Balsam, L. B., Lebl, D. R., Swijnenburg, R. J., et al. (2004). Insulin-like growth factor promotes engraftment, differentiation, and functional improvement after transfer of embryonic stem cells for myocardial restoration. Stem Cells, 22, 1239-45.

131. Kanemitsu, N., Tambara, K., Premaratne, G. U., Kimura, Y., Tomita, S., Kawamura, T., et al. (2006). Insulin-like growth factor1 enhances the efficacy of myoblast transplantation with its multiple functions in the chronic myocardial infarction rat model. Journal of Heart and Lung Transplantation, 25, 1253-1262.

132. Liu, T.-B., Fedak, P. W. M., Weisel, R. D., Yasuda, T., Kiani, G., Mickle, D. A. G., et al. (2004). Enhanced IGF-1 expression improves smooth muscle cell engraftment after cell transplantation. American Journal of Physiology Heart and Circulatory Physiology, 287, H2840-H2849.

133. Haider, H. K., Jiang, S., Idris, N. M., \& Ashraf, M. (2008). IGF1-overexpressing mesenchymal stem cells accelerate bone marrow stem cell mobilization via paracrine activation of SDF$1 \alpha /$ CXCR 4 signaling to promote myocardial repair. Circulation Research, 103, 1300-1308.

134. Rajesh, K. G., Sasaguri, S., Zhitian, Z., Suzuki, R., Asaka, R., \& Maeda, H. (2003). Second window of ischemic preconditioning regulates mitochondrial permeability transition pore by enhancing Bcl-2 expression. Cardiovascular Research, 59, 297-307.

135. Yamane, T., Dylla, S. J., Muijtjens, M., \& Weissman, I. L. (2005). Enforced Bcl-2 expression overrides serum and feeder cell requirements for mouse embryonic stem cell self-renewal. Proceedings of the National Academy of Sciences of the United States of America, 102, 3312-3317.

136. Kutschka, I., Kofidis, T., Chen, I. Y., von Degenfeld, G., Zwierzchoniewaska, M., Hoyt, G., et al. (2006). Adenoviral human BCL-2 transgene expression attenuates early donor cell death after cardiomyoblast transplantation into ischemic rat hearts. Circulation, 114(Suppl. 1), I174-I180.

137. Nakamura, Y., Yasuda, T., Weisel, R. D., \& Li, R.-K. (2006). Enhanced cell transplantation: preventing apoptosis increases cell survival and ventricular function. American Journal of Physiology Heart and Circulatory Physiology, 291, H939-H947.

138. Li, W., Ma, N., Ong, L. L., Nesselmann, C., Klopsch, C., Ladilov, Y., et al. (2007). Bcl-2 engineered MSCs inhibited apoptosis and improved heart function. Stem Cells, 25, 2118-2127.

139. Roell, W., Lewalter, T., Sasse, P., Tallini, Y. N., Choi, B. R., Breitbach, M., et al. (2007). Engraftment of connexin 43expressing cells prevents post-infarct arrhythmia. Nature, 450, 819-824.

140. Hsieh, P. C., Segers, V. F. M., Davis, M. E., MacGillivray, C., Gannon, J., Molkentin, J. D., et al. (2007). Evidence from a genetic fate-mapping study that stem cells refresh adult mammalian cardiomyocytes after injury. Nature Medicine, 13, 970974.

141. Hierlihy, A. M., Seale, P., Lobe, C. G., Rudnicki, M. A., \& Megeney, L. A. (2002). The post-natal heart contains a myocardial stem cell population. FEBS Letters, 530, 239-243.

142. Martin, C. M., Meeson, A. P., Robertson, S. M., Hawke, T. J., Richardson, J. A., Bates, S., et al. (2004). Persistent expression of the ATP-binding cassette transporter, Abcg2, identifies cardiac SP cells in the developing and adult heart. Developmental Biology, 265, 262-275.

143. Pfister, O., Mouquet, F., Jain, M., Summer, R., Helmes, M., Fine, A., et al. (2005). CD31- but not CD31+ cardiac side population 
cells exhibit functional cardiomyogenic differentiation. Circulation Research, 97, 52-61.

144. Wang, X., Hu, Q., Nakamura, Y., Lee, J., Zhang, G., From, A. H., et al. (2006). The role of the sca-1+/CD31- cardiac progenitor side population in postinfarction left ventricular remodeling. Stem Cells, 24, 1179-1788.

145. Oh, H., Bradfute, S. B., Gallardo, T. D., Nakamura, T., Gaussin, V., Mishina, Y., et al. (2003). Cardiac progenitor cells from adult myocardium: homing, differentiation, and fusion after infarction. Proceedings of the National Academy of Sciences of the United States of America, 100, 12313-12318.

146. Liang, S. X., Tan, T. Y., Gaudry, L., \& Chong, B. (2009). Differentiation and migration of $\mathrm{Sca} 1+/ \mathrm{CD} 31-$ cardiac side population cells in a murine myocardial ischemic model. International Journal of Cardiology, [Epub ahead of print].

147. Beltrami, A. P., Barlucchi, L., Torella, D., Baker, M., Limana, F., Chimenti, S., et al. (2003). Adult cardiac stem cells are multipotent and support myocardial regeneration. Cell, 114, 763-776.

148. Dawn, B., Stein, A. B., Urbanek, K., Rota, M., Whang, B., Rastaldo, R., et al. (2005). Cardiac stem cells delivered intravascularly traverse the vessel barrier, regenerate infarcted myocardium, and improve cardiac function. Proceedings of the National Academy of Sciences of the United States of America, 102, 3766-3771.

149. Bearzi, C., Rota, M., Hosoda, T., Tillmanns, J., Nascimbene, A., De Angelis, A., et al. (2007). Human cardiac stem cells. Proceedings of the National Academy of Sciences of the United States of America, 104, 14068-14073.

150. Rota, M., Padin-Iruegas, M. E., Misao, U., De Angelis, A., Maestroni, S., Ferreira-Martins, J., et al. (2008). Local activation or implantation of cardiac progenitor cells rescues scarred infarcted myocardium improving cardiac function. Circulation Research, 103, 107-116.

151. Matsuura, K., Nagai, T., Nishigaki, N., Oyama, T., Nishi, J., Wada, H., et al. (2004). Adult cardiac Sca-1-positive cells differentiate into beating cardiomyocytes. Journal of Biological Chemistry, 279, 11384-11391.
152. Messina, E., De Angelis, L., Frati, G., Morrone, S., Chimenti, S., Fiordaliso, F., et al. (2004). Isolation and expansion of adult cardiac stem cells from human and murine heart. Circulation Research, 95, 911-921.

153. Smith, R. R., Barile, L., Cho, H. C., Leppo, M. K., Hare, J. M., Messina, E., et al. (2007). Regenerative potential of cardiosphere-derived cells expanded from percutaneous endomyocardial biopsy specimens. Circulation, 115, 896908.

154. Takehara, N., Tsutsumi, Y., Tateishi, K., Ogata, T., Tanaka, H., Ueyama, T., et al. (2008). Controlled delivery of basic fibroblast growth factor promotes human cardiosphere-derived cell engraftment to enhance cardiac repair for chronic myocardial infarction. Journal of the American College of Cardiology, 52, $1858-1865$.

155. Johnston, P. V., Sasano, T., Mills, K., Evers, R., Lee, S.-T., Smith, R. R., et al. (2009). Engraftment, differentiation, and functional benefits of autologous cardiosphere-derived cells in porcine ischemic cardiomyopathy. Circulation, 120, 10751083.

156. Marbán, E. (2009). Cardiosphere-derived autologous stem cells to reverse ventricular dysfunction (CADUCEUS). ClinicalTrials. gov identifier: NCT00893360.

157. Yoon, J., Min, B. G., Kim, Y. H., Shim, W. J., Ro, Y. M., \& Lim, D. S. (2005). Differentiation, engraftment and functional effects of pre-treated mesenchymal stem cells in a rat myocardial infarct model. Acta Cardiologica, 60, 277-284.

158. Winnier, G., Blessing, M., Labosky, P. A., \& Hogan, B. L. (1995). Bone morphogenetic protein-4 is required for mesoderm formation and patterning in the mouse. Genes \& Development, 9, 2105-2116.

159. Zhang, H., \& Bradley, A. (1996). Mice deficient for BMP2 are nonviable and have defects in amnion/chorion and cardiac development. Development, 122, 2977-2986.

160. Bersell, K., Arab, S., Haring, B., \& Kuehn, B. (2009). Neuregulin1/ErbB4 signaling induces cardiomyocyte proliferation and repair of heart injury. Cell, 138, 257-270. 